\title{
GIANT CELL TUMOUR OF CAPITATE: A CASE REPORT
}

Kunal R. Bansal'1, Ajay Chandanwale2, S. Daniel ${ }^{3}$, Abhinav Bhatnagar 4

${ }^{1}$ Assistant Professor, Department of Orthopaedics, B. J. Medical College, Pune.

${ }^{2}$ Dean \& Professor, Department of Orthopaedics, B. J. Medical College, Pune.

${ }^{3}$ Associate Professor, Department of Orthopaedics, B. J. Medical College, Pune.

${ }^{4}$ Consultant, Department of Orthopaedics, Abhinav Hospital, Nagpur.

\section{ABSTRACT}

Giant cell tumours are one of the commonest benign tumours of the bone, constituting approximately $5 \%$ of all primary bone tumours. They typically occur in patients 20 to 40 years old, and there is a slight female predominance. ${ }^{[1,2]}$ Occurrence in the hand, however, particularly in the carpal bones, is rare.

\section{KEYWORDS}

Giant Cell Tumour (GCT), Lytic lesion Capitate, Carpal Bones.

HOW TO CITE THIS ARTICLE: Bansal KR, Chandanwale A, Daniel S, et al. Giant cell tumour of capitate: a case report. J. Evolution Med. Dent. Sci. 2016;5(19):986-988, DOI: 10.14260/jemds/2016/228

\section{INTRODUCTION}

Giant cell tumours are one of the commonest benign tumours of the bone, constituting approximately $5 \%$ of all primary bone tumours. They typically occur in patients 20 to 40 years old, and there is a slight female predominance. ${ }^{[3,4]}$ Occurrence in the hand, however, particularly in the carpal bones, is rare. We report a rare case of GCT of Capitate in a 28-year-old male patient.

\section{CASE REPORT}

A 28-year-old male software engineer, presented with the history of pain in the left wrist of 4 months' duration. Pain increased in severity with movements of the wrist. There was no history of trauma or pain in other joints. On examination there was fullness and tenderness over the dorsum of the wrist with painful palmar flexion and dorsiflexion at the wrist. There was decrease in terminal $20^{\circ}$ range of motion of the wrist joint compared to normal wrist. Radiograph of the left wrist anteroposterior and lateral view showed a lytic lesion in the capitate bone with thinned out cortex. All laboratory parameters were within normal limits. MRI of the wrist revealed a expansile lytic lesion in the left Capitate, without other carpal bone or joint involvement (Fig 2).

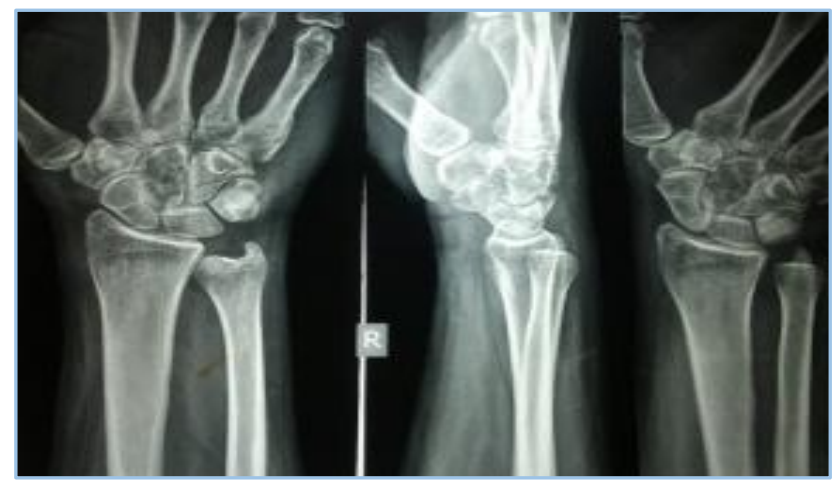

Fig. 1

Financial or Other, Competing Interest: None.

Submission 20-01-2016, Peer Review 14-02-2016,

Acceptance 22-02-2016, Published 07-03-2016.

Corresponding Author:

Dr. Kunal R. Bansal,

A-503, Ganga Melrose,

Sopan Baug,

Pune-411001

E-mail: kun_bansal@yahoo.co.in

DOI: $10.14260 /$ jemds $/ 2016 / 228$

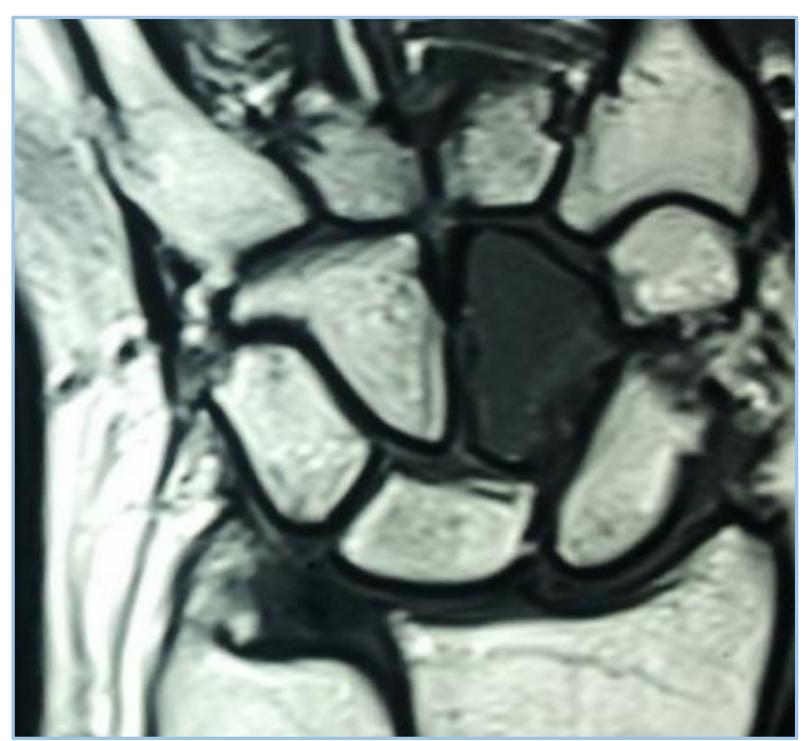

Fig. 2

Differential diagnosis at the end of imaging study included aneurismal bone cyst (ABC), giant cell tumour (GCT). Patient underwent surgery of the left Capitate through a dorsal approach (Fig. 3). The lesion was curetted (Fig 4), followed by phenol ablation and cancellous bone grafting from the patient's iliac crest. (Fig 5).

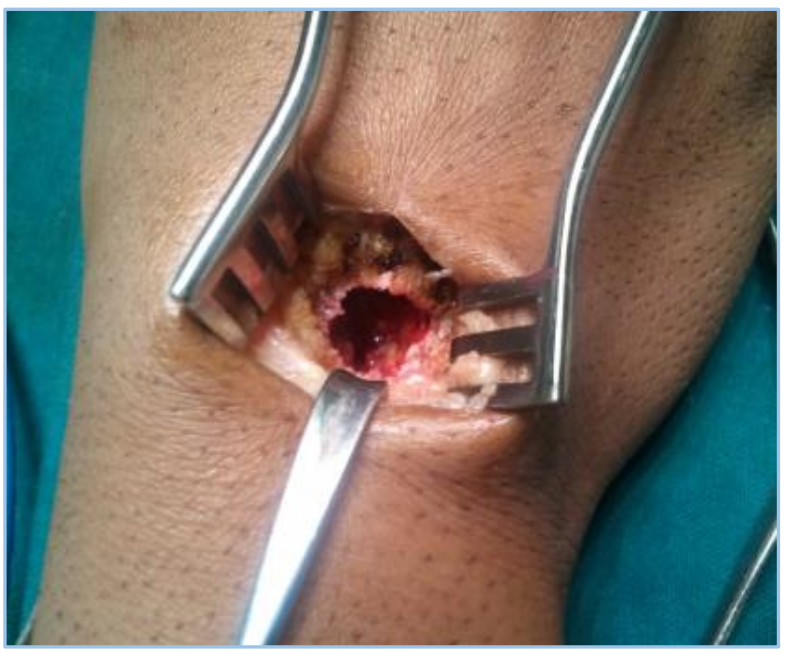

Fig. 3 


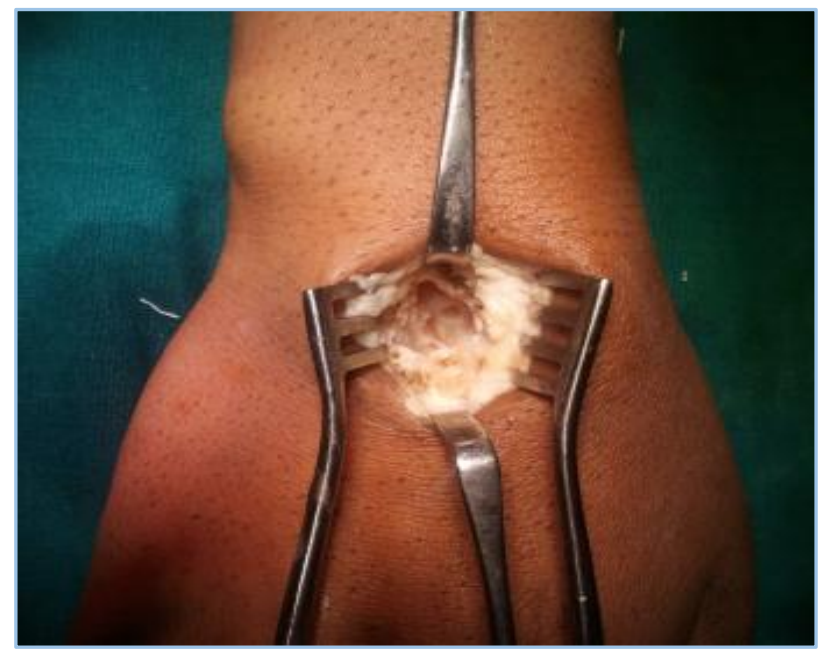

Fig. 4

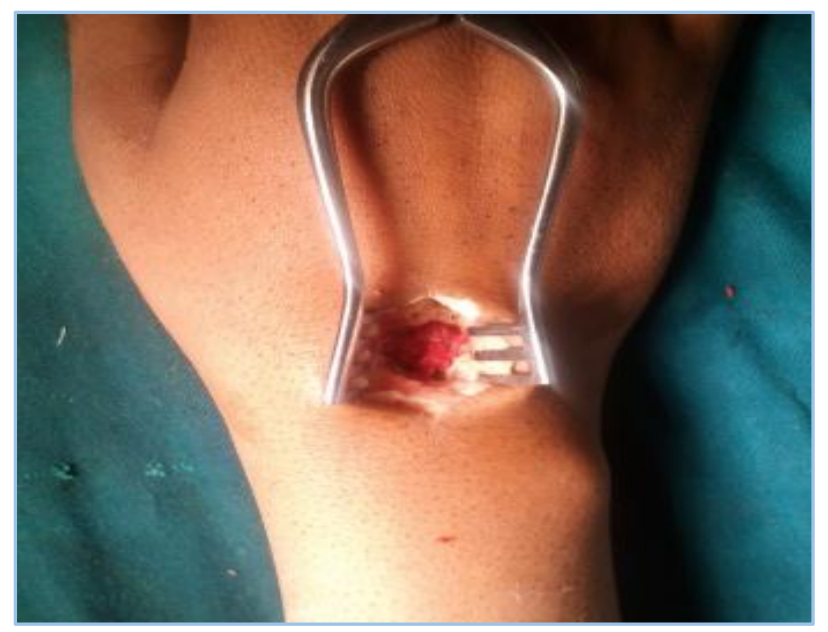

Fig. 5

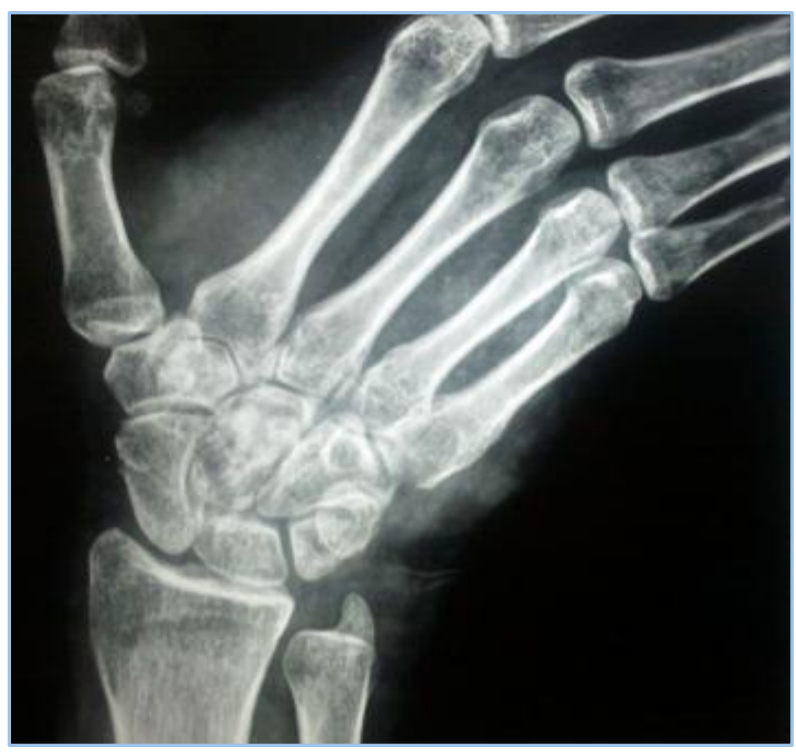

Fig. 6

Post-operative radiograph showing curettage and bone grafting. Histopathological examination of the specimen showed multinucleated osteoclast like giant cells and spindle cells stroma with plumpy nuclei consistent with the GCT. Patient was followed up clinically and radiologically at regular intervals of 6 weeks, 3 months, 6 months.
At the end of 6 months follow up, patient is symptom free and near normal range of movements and with no evidence of recurrence (Fig. 7).

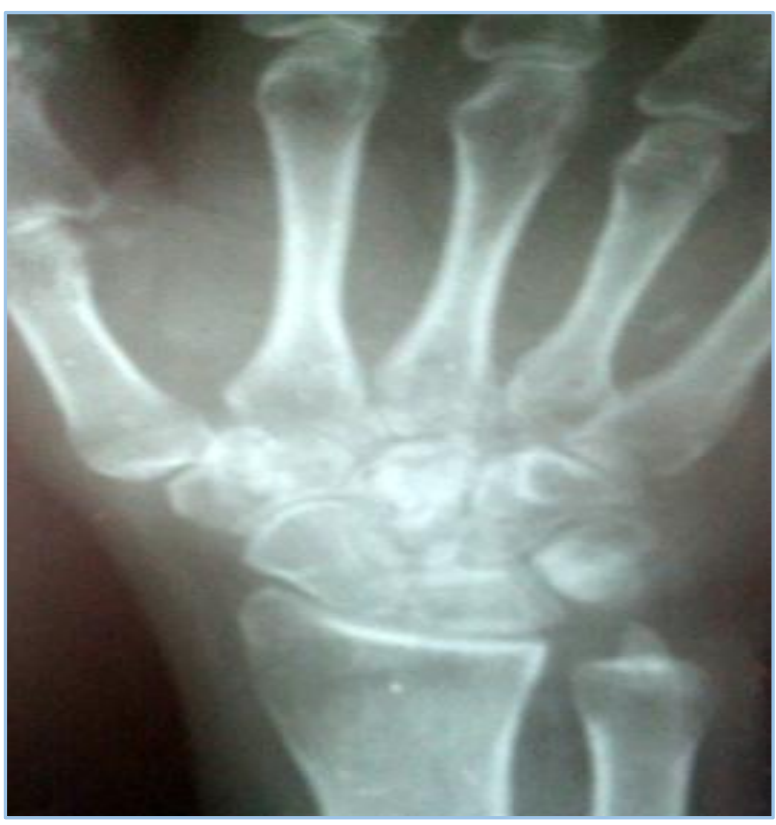

Fig. 7: Post-operative 6 Months Follow up Radiograph.

\section{DISCUSSION}

Giant cell tumours usually are solitary lesions however, $1 \%$ to $2 \%$ may be multicentric. [4] Occurrence in the hand, however, particularly in the carpal bones is rare, with reports describing cases in the scaphoid.[5] capitate.[6,7] lunate.[8] hamate.[9,10,11] and trapezium.[12] Averill et al.[4] reviewed 28 giant cell tumours in the hand. 26 were in the tubular bones and only two involved in the carpal bones. Studies have noted that GCT of hand is more frequently seen in younger individuals as in our case.[13] also another difference between hand GCT and GCT in other parts of the body is its central location as oppose to eccentric location in other bones.[14,15]

Howard and Lassen. ${ }^{[6]}$ reported a single case of giant cell tumour of the Capitate and reported finding only five additional cases of giant cell tumour of the carpal bones in the literature. Radiographically, giant cell tumours in the carpal bones resemble other lytic lesions of bone. The radiologic differential diagnosis of solitary lesions includes aneurysmal bone cyst, enchondroma, giant cell reparative granuloma.[16] brown tumour of hyperparathyroidism, posttraumatic cyst. Of these, brown tumour is the easiest to rule out in the absence of other changes of hyperparathyroidism. Giant cell reparative granuloma are very similar to the solid variant of aneurysmal bone cysts and may be considered non neoplastic and reactive. These appear similar on histologically and even the treatment of curettage and bone grafting is recommended for both the entities.[16,17,18]

This is probably related to the small volume in the hand bones.[15] where the lesion might begin eccentrically but by the time it is diagnosed, it is occupying a more central position in the bone. GCT of hand skeleton is more aggressive than other locations and is mostly multifocal. As these are rare tumours, there is no standard protocol for treatment of these lesions. 
All kinds of procedures like intralesional, marginal or wide resection are reported for treatment of these lesions.[7,15,18] Uses of adjuvents like cryotherapy and phenol ablation are reported to be useful.[17] A high recurrence rates upto $87 \%$ was reported after curettage and bone grafting, however this may just indicate difficulty in complete curettage of the lesions in small bones and may not be an indicator of aggressiveness of these tumours.[13] We believe with proper curettage and use of adjuvant these lesions can be treated with minimal complication and good functional results.

\section{CONCLUSION}

GCT of the Capitate is a rare lesion, however proper diagnosis and management yields good results. Although longer follow up will be required to comment on the recurrence rates. This case report emphasizes the rarity of the lesion with only few cases reported in literature.

\section{REFERENCES}

1. Ahlmann ER, Greene NW, Menendez LR, et al. Unusual locations for metastatic malignancy of the hand: a report of three cases. J Surg Orthop Adv 2008;17(4):267-270.

2. Athanasian EA. Malignant bone and soft-tissue sarcomas of the hand. J Am Soc Surg Hand 2004;4:60-72.

3. Athanasian EA. Aneurysmal bone cyst and giant cell tumor of bone of the hand and distal radius. Hand Clin 2004;20(3):269-281.

4. Averill RM, Smith RJ, Campbell CJ. Giant-cell tumors of the bones of the hand. J Hand Surg 1980;5A:39.

5. Kew J, Kumta SM, Leung PC. Case reports, giant-cell tumour in the scaphoid bone. Clin Radiol 2000;55(9):717-778.
6. Howard FM, Lassen K. Giantcell tumor of the capitate. J Hand Surg [Am] 1984;9(2):272-274.

7. Wilson SC, Cascio BM, Plauche HR. Giant-cell tumor of the capitate. Orthopedics 2001;24(11):1085-1086.

8. Fitz Patrick DJ, Bullough PG. Giant-cell tumor of the lunate bone: a case report. J Hand Surg [Am] 1977;2(4):269-270.

9. Plate AM, Steiner G, Posner MA. Malignant tumors of the hand and wrist. J Am Acad Orthop Surg 2006;14(12):680692.

10. Gould ES, Cooper JM, Potter HG, et al. Case report 740: Giant cell tumor of the hamate bone. Skeletal Radiol 1992;21(5):335-8.

11. Vaccari A, Monteleone M, Boselli F, et al. Giant cell tumor of the hamate bone. Chir Organi Mov 1990;75(1):77-80.

12. Weiner SD, Leeson MC. Giantcell tumor of the carpal trapezium. Orthopedics 1995;18(5):482-484.

13. Biscaglia R, Bacchini P, Bertoni F. Giant cell tumor of the bones of the hand and foot. Cancer 2000;88(9):20222032.

14. Szendroi M. Giant-cell tumour of bone. J Bone Joint Surg Br 2004;86:5-12.

15. Levine MD, De Smet AA, Neff J. Role of radiologic imaging in management planning of giant cell tumor of the bone. Skelet Radiol 1984;12:79-89.

16. Ratner V, Dorfman HD. Giant-cell reparative granuloma of the hand and foot bones. Clin Orthop Relat Res 1990;260:251-258.

17. Pintore E, Barra V, Maffulli N. Giant-cell tumor of the hamate. Case report. Scand J Plast Reconstr Hand Surg 2000;34(4):397.

18. Sanerkin NG, Mott MG, Roylance J. An unusual intraosseous lesion with? broblastic, osteoclastic, osteoblastic, aneurysmal and? bromyxoid elements: "Solid" variant of aneurismal bone cyst. Cancer 1983;51:2278-2286. 